Texas A\&M University-San Antonio

Digital Commons @ Texas A\&M University- San Antonio

2018

\title{
An Assessment of Stone Weapon Tip Standardization During the Clovis-Folsom Transition in the Western United States
}

B. Buchanan

B. Andrews

Michael J. O'Brien

Texas A\&M University-San Antonio, Mike.Obrien@tamusa.edu

M. I. Eren

Follow this and additional works at: https://digitalcommons.tamusa.edu/hist_faculty

Part of the Anthropology Commons

\section{Repository Citation}

Buchanan, B.; Andrews, B.; O'Brien, Michael J.; and Eren, M. I., "An Assessment of Stone Weapon Tip Standardization During the Clovis-Folsom Transition in the Western United States" (2018). History Faculty Publications. 14.

https://digitalcommons.tamusa.edu/hist_faculty/14

This Article is brought to you for free and open access by the College of Arts and Sciences at Digital Commons @ Texas A\&M University- San Antonio. It has been accepted for inclusion in History Faculty Publications by an authorized administrator of Digital Commons @ Texas A\&M University- San Antonio. For more information, please contact deirdre.mcdonald@tamusa.edu. 


\title{
AN ASSESSMENT OF STONE WEAPON TIP STANDARDIZATION DURING THE CLOVIS-FOLSOM TRANSITION IN THE WESTERN UNITED STATES
}

\author{
Briggs Buchanan, Brian Andrews, Michael J. O’Brien, and Metin I. Eren
}

\begin{abstract}
It has long been assumed that Folsom points are more standardized than Clovis points, although an adequate test of this proposition has yet to be undertaken. Here, we address that deficiency by using data from a sample of Folsom and Clovis points recovered from sites across the western United States. We used geometric morphometric techniques to capture point shape and then conducted statistical analyses of variability associated with Clovis and Folsom point bases and blades. Our results demonstrate that Folsom bases and blades are less variable than those on earlier Clovis points, indicating an increase in point standardization during the Early Paleoindian period. In addition, despite published claims to the contrary, Clovis and Folsom point bases are no more variable than blades. Based on these results, we conducted additional analyses to examine the modularity and size of Clovis and Folsom points. The results suggest Clovis points have more integrated base and blade segments than Folsom points. We suggest that several classes of Clovis points-intended for different functions-might have been in use during the Clovis period and that the later Folsom points might have served only as weapon tips, the shape of which were constrained by the fluting process.
\end{abstract}

Durante mucho tiempo, se ha supuesto que las puntas de proyectil Folsom son más estandarizadas que las puntas Clovis; sin embargo, hasta la fecha no se había llevado a cabo una prueba adecuada de esta propuesta. Aquí se aborda este asunto usando datos de una muestra de puntas Folsom y Clovis recuperadas en sitios del oeste de Estados Unidos. Se utilizaron técnicas de morfometría geométrica para analizar la forma de las puntas y se llevaron a cabo análisis estadísticos de la variabilidad asociada con las bases y los bordes de las puntas Clovis y Folsom. Nuestros resultados demuestran que las bases y los bordes de las puntas de proyectil Folsom son menos variables que los de las puntas Clovis. También demostramos que tanto para las puntas Clovis como para las puntas Folsom, las bases no son más variables que los bordes. Los primeros resultados indican un aumento en la estandarización de las puntas de proyectil durante el periodo Paleoindio temprano. Los resultados sugieren que la hipótesis de que el retoque aumenta la variación de forma asociada con los bordes en relación con las bases carece de fundamento. Con base en estos resultados llevamos a cabo análisis adicionales para examinar la modularidad y el tamaño de las puntas de proyectil Clovis y Folsom. Los resultados sugieren que las puntas Clovis, que son más variables en forma y longitud que las puntas Folsom, poseen segmentos de base y de borde más integrados que las puntas Folsom. Sugerimos que varias clases de puntas Clovis — destinadas para diferentes funciones - pudieron haber estado en uso durante el período Clovis y que las puntas Folsom pudieron haber servido solo como puntas de armas. Parece que la estandarización y el uso especializado de las puntas Folsom evolucionaron conjuntamente en un circuito de retroalimentación resultante tanto de las limitaciones del acanalamiento Folsom como de los beneficios para la función de la punta que pueden haber resultado del mismo acanalamiento.

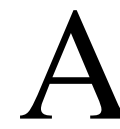

well-known transition occurred across the Great Plains, Southwest, and Rocky Mountain regions of North America beginning 12,700-12,600 cal BP (Meltzer 2009; Surovell, Boyd et al. 2016), when the Clovis culture and its iconic fluted point was replaced by

Briggs Buchanan घ Department of Anthropology, University of Tulsa, 800 South Tucker Drive, Tulsa, OK 74104, USA (briggs-buchanan@utulsa.edu, corresponding author)

Brian Andrews $\square$ Department of Psychology and Sociology, Rogers State University, 1701 Will Rogers Blvd., Claremore, OK 74107, USA

Michael J. O'Brien — Department of Humanities and Social Sciences, Texas A\&M University-San Antonio, One University Way, San Antonio, TX 78253, USA; Department of Anthropology, University of Missouri, Columbia, MO 65211, USA Metin I. Eren - Department of Anthropology, Kent State University, 750 Hilltop Drive, Kent, OH, USA; Department of Archaeology, Cleveland Museum of Natural History, 1 Wade Oval Drive, Cleveland, OH 44106, USA

American Antiquity 83(4), 2018, pp. 721-734

Copyright $($ C) 2018 by the Society for American Archaeology

doi:10.1017/aaq.2018.53 
the Folsom culture and its likewise iconic point. Until 12,900-12,700 cal BP (Waters and Stafford 2007, 2014), western Clovis groups hunted a variety of prey, including, on occasion, now-extinct megafauna such as mammoth and large bison (DeAngelis and Lyman 2016; Emery-Wetherell et al. 2017; Grayson and Meltzer 2015; Meltzer 2015; Surovell, Pelton et al. 2016). This period encompassed a climate that changed from global warming at the end of the Pleistocene to global cooling during the first century of the Younger Dryas (Sellet 2018; Straus and Goebel 2011).

Folsom technology began to replace Clovis technology in a process of technological or demic diffusion that appears to have originated on the northern Plains (Collard et al. 2010; Surovell, Boyd et al. 2016). There, Folsom hunters focused on bison, which necessitated high residential mobility and large home ranges (Amick 1996; Andrews et al. 2008; Hofman 1999, 2002; Jennings 2012, 2016; Jennings et al. 2010; Kelly and Todd 1988). In more topographically varied settings, such as river valleys and the foothills of the Rocky Mountains, Folsom subsistence was more diverse (Cannon and Meltzer 2008; Kornfeld and Larson 2008). The Folsom culture, set in the Younger Dryas (Meltzer and Holliday 2010), lasted until approximately 12,200 cal BP, only four or five centuries after it first appeared (Surovell, Boyd et al. 2016).

Differences in the key diagnostic features of the Clovis and Folsom complexes-both flaked stone projectile points-are well documented. Clovis points are bifacially flaked and lanceolate in shape, with parallel to slightly convex sides, concave bases, and short basal flutes that extend one-quarter to one-third of a point's length (Wormington 1957). An empirically supported function of Clovis flutes is that they were shock absorbers, which redistributed stress and relocated damage in order to prevent catastrophic failure (Thomas et al. 2017). Folsom points are lanceolate or lozenge-shaped and usually smaller and lighter than Clovis points, with flute scars that travel two-thirds or more of the point's length. There are currently no empirically well-supported hypotheses for the precise function(s) of Folsom fluting (Ahler and Geib 2000; Sellet 2018), although it likely was a kind of improvement on Clovis fluting.
Explanations for the apparent size difference between Clovis and Folsom points have focused on differences in delivery system and the availability and size of prey. Recent evidence suggests that the delivery system was not a factor, as both Clovis and Folsom points appear to have been used with the atlatl and dart (Hutchings 2015). Buchanan and colleagues (2011) found some support for the prey hypothesis, showing that Clovis and Folsom points used to hunt bison were smaller than Clovis points used to hunt mammoth, but they also noted a size difference between Clovis points used to hunt bison and Folsom points, with the latter being smaller.

It has long been proposed that, as a group, Folsom points are more uniform in shape and size than Clovis points (Ahler and Geib 2000; Boldurian 1990; Frison and Bradley 1980; Tunnell and Johnson 2000; Wilmsen and Roberts 1978). An influential study by Judge (1973) compared coefficients of variation for a suite of measurements taken on a sample of Clovis and Folsom points from the middle Rio Grande Valley of New Mexico. He primarily measured point bases, arguing that the base was the critical area where points were affixed to darts and hence less subject to changes resulting from resharpening (but see Buchanan et al. 2015). The study showed that Folsom points were less variable than Clovis points, although Judge cautioned that further studies using materials from beyond the middle Rio Grande Valley were needed.

Several other researchers observed the relative uniformity of Folsom points noted by Judge. Boldurian and colleagues (1985), for example, suggested that Folsom base widths were standardized to fit an anvil and backstop device used to remove channel flakes from Folsom preforms, although Folsom knapping and fluting can be done much more easily with direct percussion (Patten 2002, 2005). Ahler and Geib (2000) also linked the perceived uniformity of Folsom to the process of fluting and hafting. They argued that Folsom points served as replaceable components in the weapon system and that the point was designed to be fitted precisely into a haft. If dulled or damaged, the point could be resharpened and reset in the haft for continued use (see also Bement 2016). Thus, the uniformity of Folsom point bases has been argued to be 
purposely standardized to fit interchangeably into hafts and to reduce risk of failure when hunting bison (Ahler and Geib 2000; Amick 1994; Boldurian et al. 1985; Hofman 1991, 1992, 2003; Hunzicker 2008; Kelly and Todd 1988; Surovell 2009).

Our study extends Judge's analysis beyond the middle Rio Grande Valley and examines a large sample of points from across the Folsom range of the Great Plains, Rocky Mountains, and Southwest. Although our primary focus is on point shape, given our belief that shape is a critical aspect of form in terms of performance characteristics (e.g., Cheshier and Kelly 2006), we also tested for differences in the variability of Folsom and Clovis point size. We conducted four sets of analyses. First, we tested for differences in the amount of variation in maximum length and maximum width of Clovis and Folsom points. Second, we tested the hypothesis that Folsom bases are more standardized in shape than Clovis bases. To conduct this research, we captured base shape by using geometric morphometrics (GM), which is a suite of methods that remove the effects of size prior to shape analysis (Dryden and Mardia 1998; O'Higgins 2000; Slice 2005, 2007), and then applied statistical tests of variation. Third, we compared Folsom and Clovis blade-shape variation. A previous study by Buchanan and colleagues (2012) demonstrated that, at least with Clovis, blades and bases exhibit similar levels of variation, suggesting that if blades were resharpened, they were under similar constraints as bases. With this idea in mind, we carried out analyses that compared variation in Folsom blade shape to Clovis blade shape. Fourth, we compared Folsom base-to-blade variation to Clovis base-to-blade variation to determine if the results of the study by Buchanan and colleagues could be replicated.

\section{Materials and Methods}

We examined Clovis and Folsom points in assemblages from across the western United States. The Clovis point sample $(n=125)$ is described in previous studies (Buchanan et al. 2011, 2014) and includes specimens from wellknown assemblages from the Great Plains,
Rocky Mountains, Southwest, and Northwest (Figure 1; see Supplemental Table 1). The Folsom point sample $(n=156)$ is more spatially restricted and includes points from sites located in the Great Plains, Rocky Mountains, and Southwest (Figure 1).

For the size analysis, we used published measurements of maximum length and width, or in some cases took measurements on the artifacts ourselves. Because neither variable conformed to normality according to Shapiro-Wilk tests (length: $W=0.794, p<0.000$; width: $W=0.832$, $p<0.000$ ), we used distribution-free FlignerKilleen (FK) tests to compare coefficients of variation (CV) among the samples (Fligner and Killeen 1976). The CV normalizes the amount of variation in a set of measurements and is calculated by dividing the sample standard deviation by the sample mean and multiplying the quotient by 100. The FK test statistically assesses differences in these measures.

For our shape analyses, we used digital images of Clovis and Folsom points to record landmark positions that were subsequently analyzed with GM methods. Clovis and Folsom point images were taken by the first author, or in cases where collections were not available or were not visited, suitable published images were used. The point images were used for two-dimensional landmark digitization and subsequent GM analysis. Three primary landmarks were positioned on the digital image of each point, one at the tip and two at the basal ears. Twenty semilandmarks were placed between the primary landmarks using a procedure that makes their positions geometrically correspondent (Lycett and von Cramon-Taubadel 2013). Superimposed, equally spaced line segments drawn between the primary landmarks provided the framework for the placement of semilandmarks. The number of landmarks was the same as in our previous studies (e.g., Buchanan et al. 2011, 2014), making the new analyses comparable. This number of landmarks provides a level of detail that has been shown to effectively capture the relevant aspects of Paleoindian point shape differences. Increasing the number of landmarks undoubtedly would provide a finer-grain view of shape but would also have the detrimental effect of eventually rendering each specimen as being unique. 


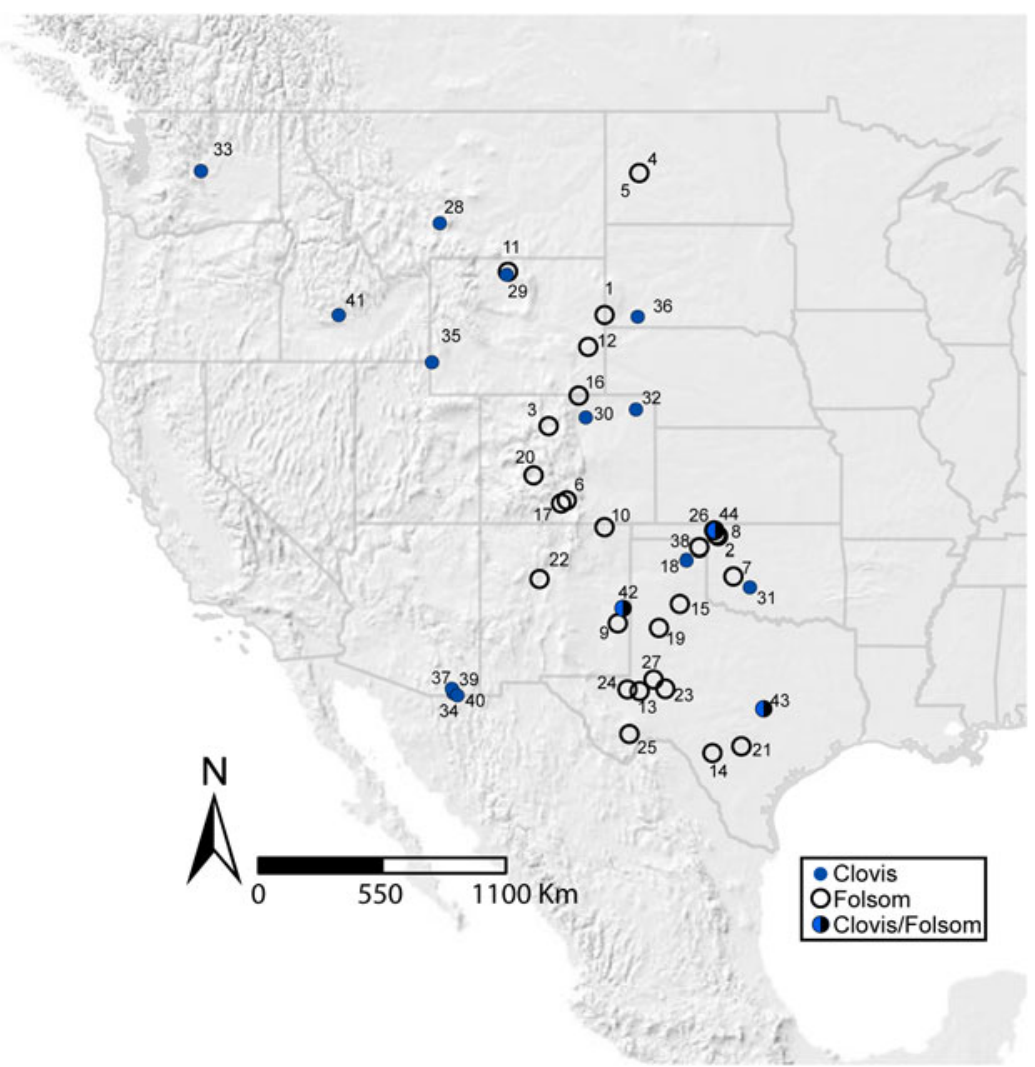

Figure 1. Map of the western United States showing the location of sites included in the analysis. Key: Folsom Sites - 1 Agate Basin, 2 Badger Hole, 3 Barger Gulch, 4 Big Black, 5 Bobtail Wolf, 6 Cattle Guard, 7 Cedar Creek, 8 Cooper, 9 Elida, 10 Folsom, 11 Hanson, 12 Hell Gap, 13 Hot Tubb, 14 Kincaid, 15 Lake Theo, 16 Lindenmeier, 17 Linger, 18 Lipscomb, 19 Lubbock Lake, 20 Mountaineer, 21 Pavo Real, 22 Rio Rancho, 23 Scharbauer, 24 Shifting Sands, 25 Shirey Flats, 26 Waugh, 27 Wyche Ranch. Clovis Sites - 28 Anzick, 29 Colby, 30 Dent, 31 Domebo, 32 Drake, 33 East Wenatchee, 34 Escapule, 35 Fenn, 36 Lange Ferguson, 37 Lehner, 38 Miami, 39 Murray Springs, 40 Naco, 41 Simon. Multicomponent Clovis/Folsom Sites - 42 Blackwater Draw/Mitchell, 43 Gault, 44 Jake Bluff. (Color online)

Following the digitization of the landmark configurations, we carried out a superimposition procedure using the tpsSuper program (Rohlf 2015a), which centers and scales the landmark configurations to unit centroid size to reduce size effects. After that, an average, or consensus, configuration was computed. From that consensus configuration, individual landmark configurations were translated and rotated using least-squares criteria to minimize residual differences between sets of landmarks. The resulting variation among the landmark positionsProcrustes residuals - are interpreted as shape differences in Kendall shape space. Projection to the tangent Euclidean space and extraction of partial warps (eigenvectors of the bendingenergy matrix that describe local deformation along a coordinate axis) and the uniform component (global information on deformation) were performed using the tpsSmall (Rohlf 2015b) and tpsRelw programs (Rohlf 2016), respectively. Partial warps and uniform components represent all information about the shape of specimens (Rohlf et al. 1996; Slice 2005). Lastly, relative warps were computed from the partial warps using the tpsRelw program. Relative warps are the principal components of the shape variables - the partial warps - and reflect the major patterns of shape variation within a group of specimens (Rohlf 1993).

We conducted the GM procedures outlined above separately on the base and blade configurations of the Clovis and Folsom points (Figure 2). Base configurations were calculated using two 


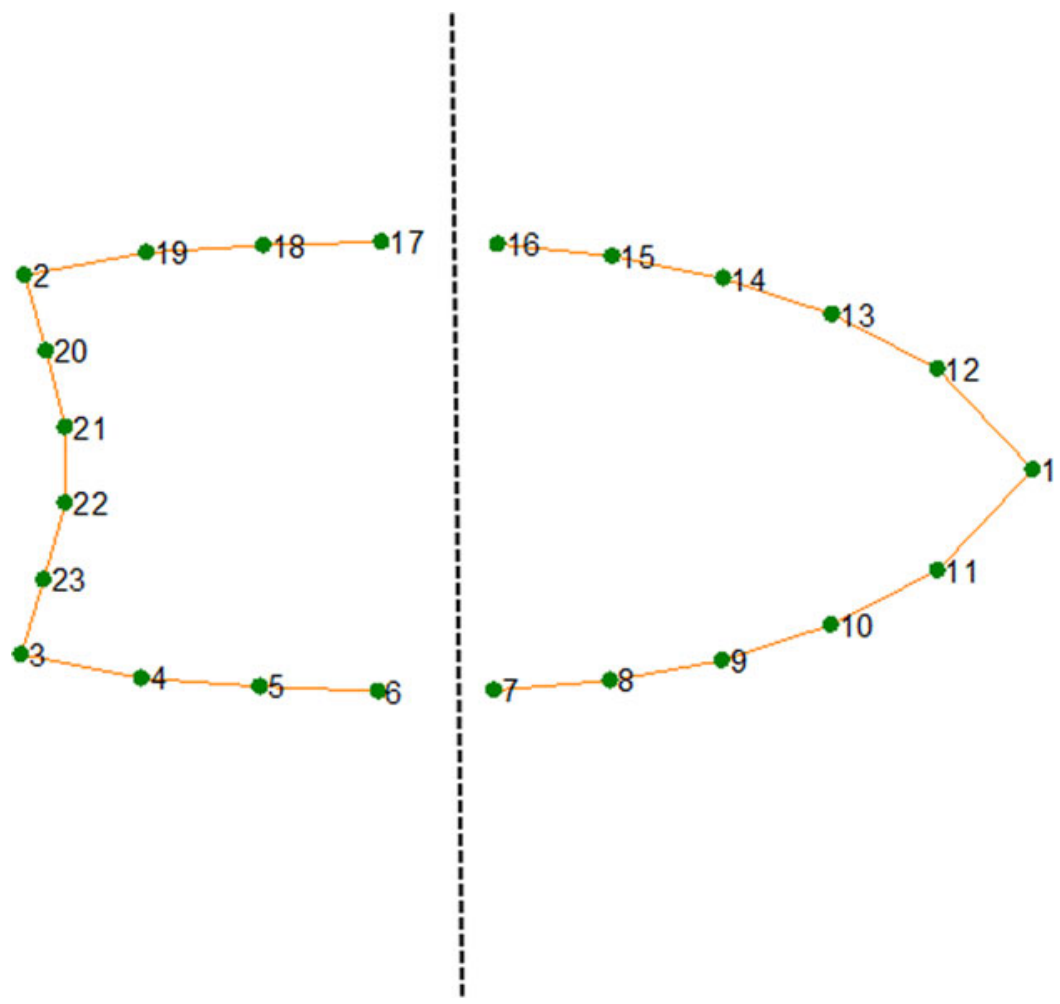

Figure 2. Image of the consensus configuration for Clovis and Folsom points $(n=281)$ with landmarks shown in gray (green online). Primary landmarks are labeled 1-3; the dashed line demarcates the split between base and blade configurations. The base configuration consists of landmarks 2-6 and 17-23, and the blade configuration consists of landmarks 1 and 7-16. (Color online)

primary landmarks (the basal ear tips; see Figure 2, numbers 2 and 3) and 10 semilandmarks (see Figure 2, numbers 4-6, 17-19, and 20-23). Blade configurations were calculated using the first primary landmark-located at the tip - and 10 semilandmarks (see Figure 2, numbers 7-11 and 12-16).

After obtaining the relative warps for both the base and blade landmark configurations, we visually and statistically compared the variance of the Clovis sample to that of the Folsom sample. Relative warps, like principal components, reduce variation in a dataset to a smaller number of variables that capture different aspects of the overall variation. In conducting our comparison, we first visually assessed bivariate plots of the first two relative warps for the base and blade datasets, then used the $F$ test to evaluate differences in variance. This technique tests the hypothesis that the variances in the groups are equal- that is, the difference between the variances is zero. If the test is significant at the $p<0.05$ level, then we conclude that the null hypothesis is incorrect and that the variances differ significantly. Prior to conducting the $F$ tests, we used Shapiro-Wilk tests (Razali and Wah 2011) to determine that the variables exhibited normal distributions. The results indicated that one variable (relative warp 1 for Folsom bases) was significantly different from normal (Supplemental Table 2), and thus we report nonparametric Monte Carlo-derived $p$-values. The Monte Carlo procedure does not rely on the normal distribution to derive a $p$-value; instead, it calculates the difference in variance in 9,999 permutations of the data and compares these to the original difference to calculate the $p$-value. We carried out statistical tests using the free software PAST 3.01 (Hammer et al. 2001). 


\section{Results}

\section{Comparing Clovis and Folsom Size Variation}

Clovis points are on average longer and wider than Folsom points (Supplemental Table 3), and the FK tests show that the associated coefficients of variation for length $(T=188.22 ; p<$ $0.000)$ and width $(T=188.4 ; p<0.000)$ are statistically different between Clovis and Folsom points. Clovis points are more variable than Folsom in both size measures.

\section{Comparing Clovis and Folsom Base-Shape Variation}

The first two relative warps of the Clovis and Folsom base landmark configurations account for $91.32 \%$ of the overall variation in the dataset. The first relative warp (RW1) captures most of the variation $(84.76 \%)$. Base shape along the
RW1 axis changes from narrow, long bases with bell-shaped basal indentations on the positive, or right, side of the axis to wide, short bases with shallow concave basal indentations on the negative, or left, side (Figure 3). Clovis bases are distributed primarily along the positive end of the RW1 axis (mean = 0.104), and Folsom bases are centered on the negative end (mean $=$ -0.083 ). The second relative warp (RW2) accounts for only $6.55 \%$ of the overall variation. Shape variation along the RW2 axis is represented primarily by depth of basal concavity, ranging from shallow on the positive, or upper, end of the axis to deeply concave and more constricted on the negative, or lower, end. On the RW2 axis, both Clovis and Folsom bases are centered very close to the zero midline, with Clovis bases centered on the positive side (mean $=0.008)$ and Folsom bases positioned on the negative side $($ mean $=-0.007)$.

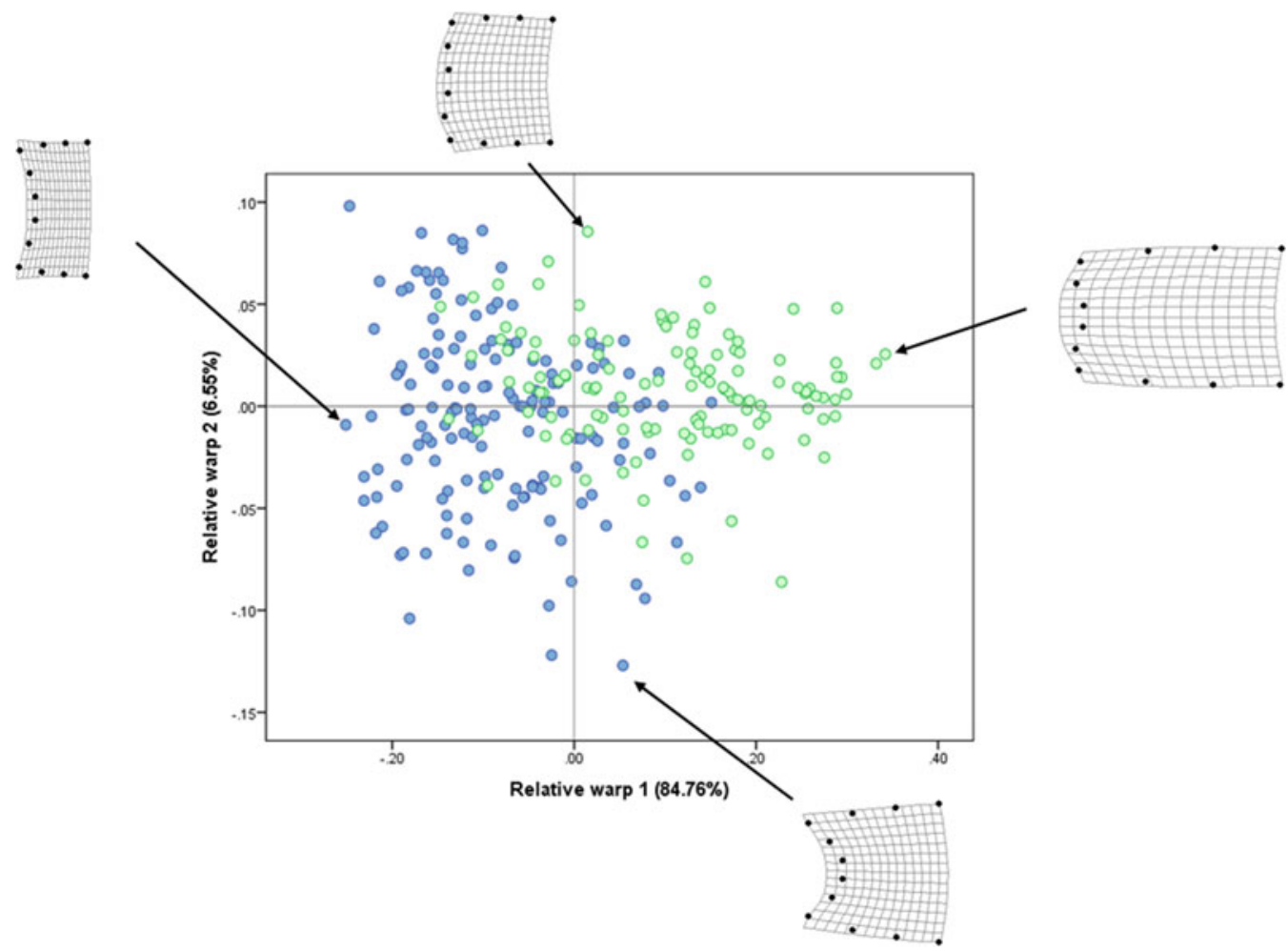

Figure 3. Bivariate plot of Clovis (green circles, light gray in print) and Folsom (blue circles, dark gray in print) baseshape variation. The $X$-axis shows relative warp 1 scores, representing $84.76 \%$ of the overall variation in the dataset, and the $\mathrm{Y}$-axis shows relative warp 2 scores, representing $6.55 \%$ of the overall variation. The four point-base images are deformations from the consensus configuration that are used to display the shape space defined by the first two relative warps. (Color online) 
Clovis bases have nearly double the amount of variation along the RW1 axis. Results of $F$ tests confirm this observation: Clovis base shapes are significantly more variable than Folsom bases for RW1 (Table 1). For RW2 scores, representing about $6 \%$ of the overall variation, Folsom bases are more variable than Clovis bases.

\section{Comparing Clovis and Folsom Blade-Shape Variation}

For Clovis and Folsom blade shapes, the first two relative warps encompass $97.25 \%$ of the overall variation, with RW1 representing 93.15\%. Blade shape along that axis changes from long and narrow on the positive, or right, side to short and wide on the negative, or left, side (Figure 4). Clovis blades are located primarily at the positive end of the RW1 axis (mean=0.122) and Folsom blades primarily at the negative end (mean $=-0.098$ ). RW2 accounts for only $4.10 \%$ of the variation. Shape variation along that axis is represented by specimens with converging proximal blades at the positive, or upper, end and by specimens with expanding proximal blades at the negative, or lower, end. On the RW2 axis, average Clovis and Folsom blades are close to the zero midline, with Clovis bases located on the negative side (mean $=-0.0055$ ) and Folsom bases on the positive side (mean = 0.0044).

An $F$ test showed that Clovis blades are significantly more variable than Folsom blades along the primary RW1 axis (Table 2). Along the RW2 axis, which, again, represents only $4.10 \%$ of the overall variation, an $F$ test indicated

Table 1. Mean and Variance of Relative Warp (RW) Scores Associated with Clovis $(n=125)$ and Folsom $(n=156)$ Bases. Results of Tests for Equal Variances between Clovis and Folsom Relative Warp Scores Are Reported in the Last Two Columns.

\begin{tabular}{lrccc}
\hline & Mean & Variance & $F$ & $\begin{array}{c}\text { Monte Carlo } \\
p \text {-value }\end{array}$ \\
\hline RW1 Clovis & 0.104 & 0.014 & 1.72 & $0.002^{*}$ \\
RW1 Folsom & -0.083 & 0.008 & & \\
RW2 Clovis & 0.008 & 0.001 & 2.54 & $<0.000^{*}$ \\
RW2 Folsom & -0.007 & 0.002 & & \\
\hline
\end{tabular}

*Indicates significance using the Bonferroni adjusted significance level of $\alpha=0.025$. that Folsom blades are more variable than Clovis blades.

\section{Comparing Base-to-Blade Variation within Types}

A follow-up analysis to the base and blade comparisons between Clovis and Folsom examined the variability between the base and the blade within the type samples. Buchanan and colleagues (2012) found that for Clovis points, basal measurements were not more variable than blade measurements. The results of our analysis agree with their finding and extend it to Folsom (Table 3). For both relative warps 1 and 2, Folsom bases have similar levels of variation to Folsom blades. This is also true for Clovis bases and blades.

\section{Discussion}

Judge's (1973) well-known finding that Folsom bases are more standardized than Clovis bases was based on a small sample of Early Paleoindian points from the middle Rio Grande Valley of New Mexico. We extended Judge's sample both in size and spatial coverage to provide a comprehensive test of the hypothesis. The findings from our first three sets of analyses are consistent with Judge's original results: Folsom points are shorter, narrower, and less variable than Clovis points; Folsom bases are less variable than Clovis bases; and Folsom blades are less variable than Clovis blades. Our results show that this pattern holds across western North America and is not limited to the region of New Mexico where Judge conducted his study.

Our fourth set of analyses compared base and blade variation within types. Judge (1973) hypothesized that the basal portion of Early Paleoindian points would be less variable than blade portions, as he assumed the latter would have been subject to resharpening. A study by Buchanan and colleagues (2012) indicated that this was not the case for Clovis points. Our results provide further support for Buchanan and colleagues' (2012) comparison of Clovis base and blade measurements: Clovis blades are not more variable than Clovis bases. We also compared variation in Folsom bases to that 


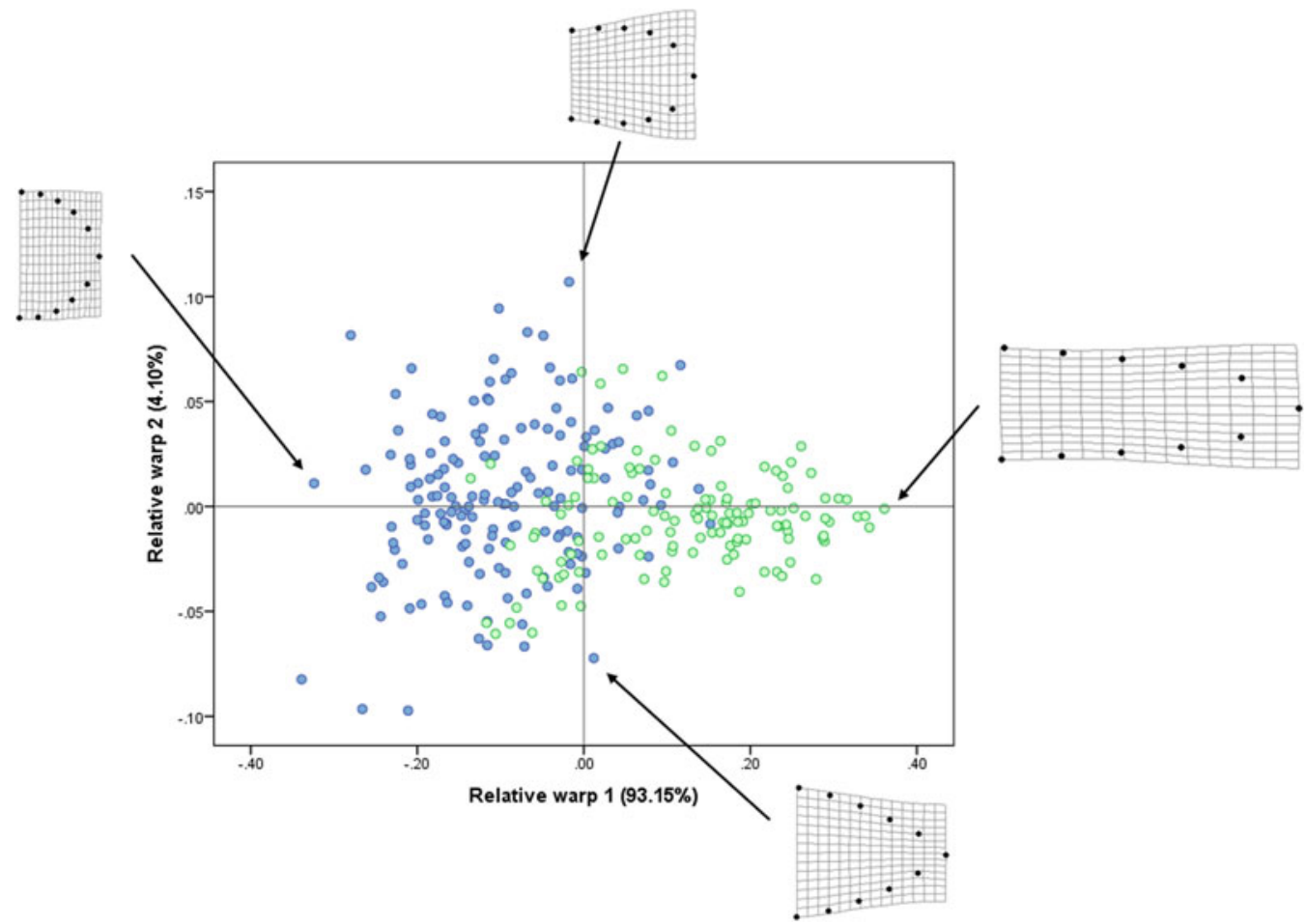

Figure 4. Bivariate plot of Clovis (green circles online, light gray in print) and Folsom (blue circles online, dark gray in print) blade-shape variation. The $X$-axis shows relative warp 1 scores, representing $93.15 \%$ of the overall variation in the dataset, and the $Y$-axis shows relative warp 2 scores, representing $4.10 \%$ of the overall variation. The four pointblade images are deformations from the consensus configuration that are used to display the shape space defined by the first two relative warps. (Color online)

in Folsom blades and found the same result: Folsom blades are not more variable than Folsom bases. These results call into question the generally untested assertion that resharpening results in more shape variation in Paleoindian point blades relative to bases (Thulman 2012). Rather,

Table 2. Mean and Variance of Relative Warp (RW) Scores Associated with Clovis $(n=125)$ and Folsom $(n=156)$ Blades. Results of Tests for Equal Variances between Clovis and Folsom Relative Warp Scores Are Reported in the Last Two Columns.

\begin{tabular}{lcccc}
\hline & Mean & Variance & $F$ & $\begin{array}{c}\text { Monte Carlo } \\
p \text {-value }\end{array}$ \\
\hline RW1 Clovis & 0.122 & 0.014 & 1.53 & $0.002^{*}$ \\
RW1 Folsom & -0.098 & 0.009 & & \\
RW2 Clovis & -0.0055 & 0.0006 & 2.44 & $<0.000^{*}$ \\
RW2 Folsom & 0.0044 & 0.0013 & & \\
\hline
\end{tabular}

*Indicates significance using the Bonferroni adjusted significance level of $\alpha=0.025$. if resharpening was consistently applied to point blades, the consequence was size reduction of the blade, with little effect on blade shape. These results are consistent with findings by Buchanan

Table 3. Tests of Homogeneity of Variance between Base and Blade Portions of Clovis $(n=125)$ and Folsom $(n=156)$ Points.

\begin{tabular}{lccc}
\hline $\begin{array}{l}\text { Base-to-Blade } \\
\text { Comparison }\end{array}$ & $F$ & $p$-value* & $\begin{array}{c}\text { Monte Carlo } \\
p \text {-value }\end{array}$ \\
\hline $\begin{array}{l}\text { Folsom relative warp 1 } \\
\quad \text { scores }\end{array}$ & 1.155 & 0.370 & 0.326 \\
$\begin{array}{l}\text { Clovis relative warp 1 } \\
\text { scores }\end{array}$ & 1.027 & 0.880 & 0.835 \\
$\begin{array}{c}\text { Folsom relative warp 2 } \\
\quad \text { scores }\end{array}$ & 1.442 & 0.023 & 0.024 \\
$\begin{array}{l}\text { Clovis relative warp 2 } \\
\text { scores }\end{array}$ & 1.387 & 0.067 & 0.123 \\
\hline
\end{tabular}

*Indicates significance using the Bonferroni adjusted significance level of $\alpha=0.0125$. 
and Collard (2010) and Buchanan and colleagues $(2012,2015)$.

Several researchers have offered explanations for the original observation made by Judge (1973) - and supported in our study - that Folsom is more uniform than Clovis. The most common explanation, and one for which Judge was himself a proponent, is that Folsom bases were standardized so that they could fit precisely designed haft systems (Ahler and Geib 2000; Bement 2016; Boldurian 1990). Further, it usually is argued that because Folsom hunters relied heavily on mobile and difficult-to-locate preyprimarily bison-they invested considerable time and energy in the design of their points and delivery systems. The standardization of Folsom points is suggested to have allowed hunters to easily resharpen (Ahler and Geib 2000) or replace (Bement 2016) damaged points. Another closely related explanation for the uniformity of Folsom bases suggests more specifically that the process of fluting, which is believed to be integral to hafting, imposed strict constraints on the form of Folsom bases (Ahler and Geib 2000). Our findings are consistent with these explanations and may also provide evidence to further develop the details of the arguments. We believe a key to explaining why Folsom points are relatively more standardized than Clovis points has to do with activities attributed to the latter but perhaps not the former: cutting, slicing, and butchery.

Note that our results suggest that both point base and blade variability decreased over time from the Clovis to Folsom periods. This finding is consistent with the hypothesis that Folsom point standardization was the result of withintool-kit specialization. Use-wear studies of Clovis points indicate they served as knives as well as weapon tips (Kay 1996; Miller 2013; Smallwood 2006), but to our knowledge, no such multifunctionality has been noted for Folsom points. Indeed, use-wear analyses of Folsom points indicate mainly hafting damage, with no evidence of cutting wear (Ahler and Geib 2000). Further, ultrathin bifaces, which are common occurrences in Folsom assemblages, are often viewed as specialized knives (Jodry 1999; Root et al. 1999). When our results are considered in light of the above, the emerging picture indicates that variability in Clovis points relative to that in Folsom points reflects the evolution of one multifunctional tool into two specialized tools. This specialization of use among points is likely part of a suite of changes in Folsom stone acquisition and stone tool manufacture and usage that occurred as populations settled into increasingly familiar landscapes (see Buchanan et al. 2018).

To further examine the possibility that Folsom points were more specialized functionally than Clovis points, we examined the modularity, or morphological integration (Klingenberg 2009), of Clovis and Folsom points. Modularity in this context is expressed as different subsets of a point operating independently (González-José and Charlin 2012). We defined two potential modules, the base and the blade (as outlined above). If modularity is weak, covariation between the base and blade will be high, whereas if modularity is strong, covariation will be low. Based on the hypothesis posited by several researchers (e.g., Ahler and Geib 2000; Bement 1999, 2016; Judge 1973), Folsom points are expected to be modular, meaning that the blade is a component that was designed to be reworked and reduced with use, whereas the base was standardized to fit particular hafting elements.

To investigate the modularity hypothesis, we used the software MorphoJ (Klingenberg 2011) to determine the covariation between the base and blade sections of Clovis and Folsom points. Our results showed that the base and blade components of Folsom points do indeed have stronger modularity, or lower covariation $(R V$ coefficient $=0.76)$, than do Clovis points $(R V$ coefficient $=0.89$ ). Thus, the base and blade portions of Folsom points are less integrated than they are in Clovis points and lend support to the hypothesis that the separate portions of Folsom points were independent modules: one module for precise hafting and the other for penetrating prey.

This finding leads us to ask, if Clovis points served as multifunctional tools and are more variable than Folsom, why are the base and blade segments more integrated for Clovis than Folsom? We suggest that the high covariation between base and blade modules in Clovis points is potentially indicative of the existence of different forms of Clovis points with different 
intended functions. A comparison of Clovis and Folsom point lengths shows the variability in Clovis relative to Folsom (Figure 5). In particular, there is a much wider range for Clovis, which suggests that points of different lengths served different functions. Short Clovis points might have been used primarily for hunting, whereas medium-sized and larger points might have been used for both hunting and butchering tasks.

Another question raised by our study concerns the relation between the emergence of Folsom point standardization and specialization versus the iconic full-face fluting of Folsom. Building off the hypotheses that have been developed previously (Ahler and Geib 2000; Bement 1999, 2016; Boldurian 1990; Boldurian et al. 1985), we propose that there likely was positive feedback between increasing flute length and point standardization, on the one hand, and functional specialization, on the other. Clovis fluting appears to be a functional attribute that allows a point to absorb significantly more energy, last longer, and remain intact relative to unfluted points (Thomas et al. 2017). The longer channel flakes removed from Folsom points appear to be exaggerations and extensions of a process that began with Clovis (Patten 2002). This elongation of the channel flake could have been a consequence of Early Paleoindian knappers identifying the benefits of a flute and attempting to augment those benefits by increasing its length.

As flutes became longer, and more difficult to remove successfully, a specific sequence of knapping and a set of "process controls" evolved (Patten 2005). This sequence is convergent with Levallois technology (Figure 6) in that a convexity is intentionally prepared, as is a specialized platform that must be directly struck. As this practice continued, proto-Folsom knappers could have recognized two benefits to their longerfluted points. First, the nascent Folsom knapping sequence automatically resulted in increased point plan-view standardization. The geometry of Folsom points prior to flute removal-as Lycett and von Cramon-Taubadel (2013) found with Levallois cores that, like Folsom points, appear to be isometrically scaled (Lycett et al.

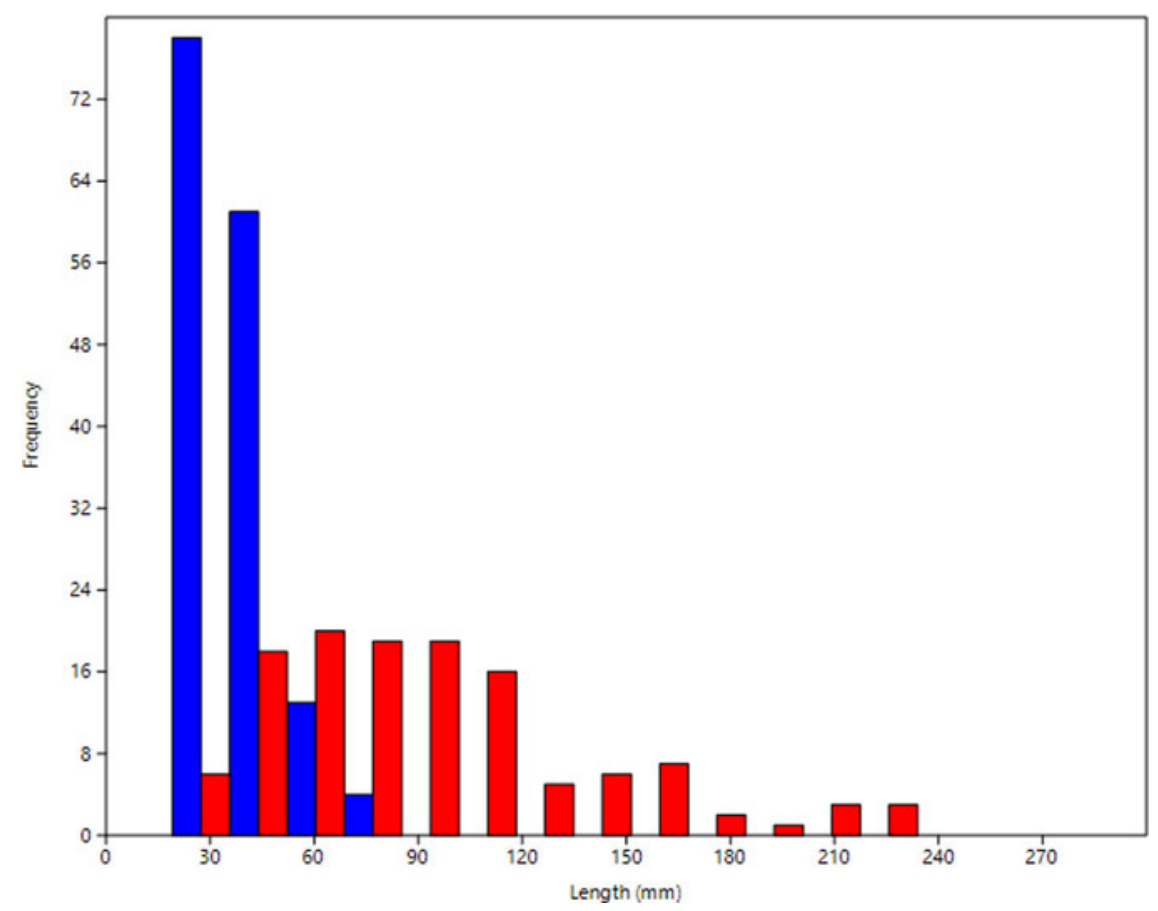

Figure 5. Histogram of Clovis point lengths (red bars online, light gray in print) and Folsom point lengths (blue bars online, dark gray in print) for specimens in the study. (Color online) 

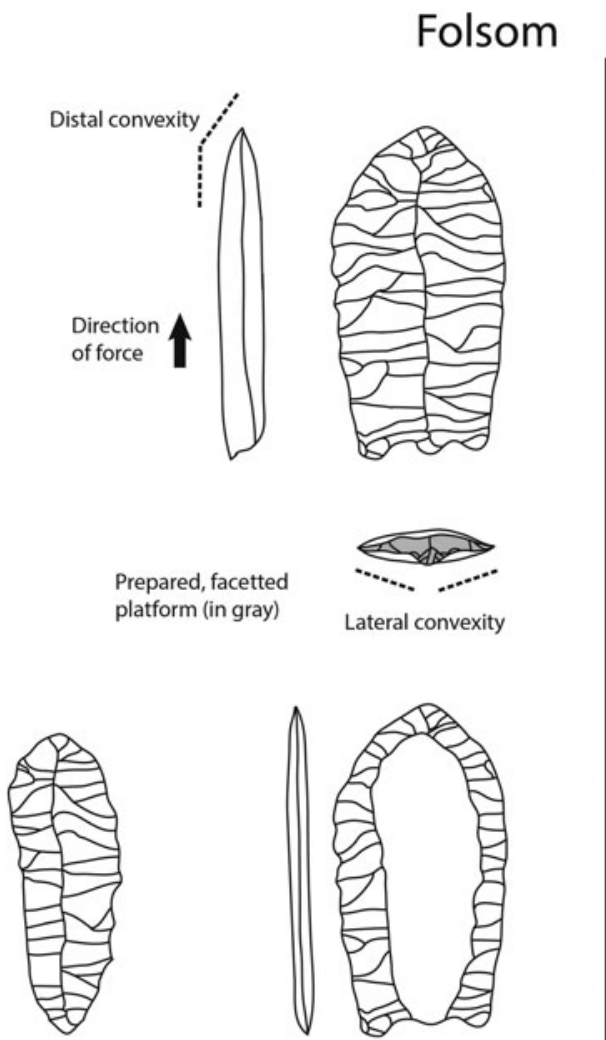

Removed channel flake (discarded)

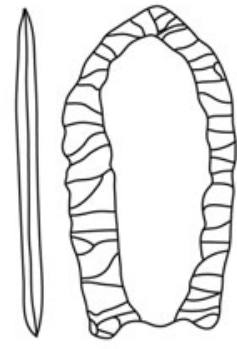

Object with large flake scar (kept)

\section{Levallois}
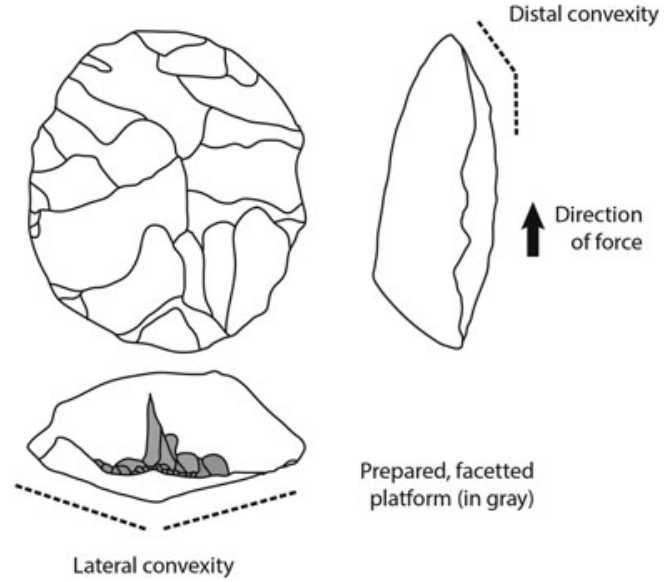

Prepared, facetted platform (in gray)

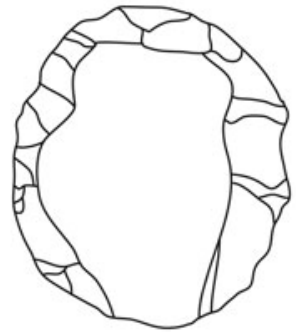

Object with large flake scar (discarded or reprepared)

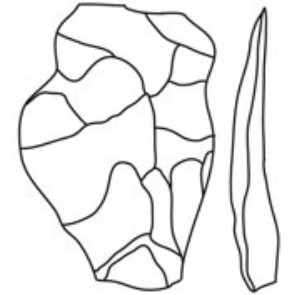

Removed Levallois flake (kept)

Figure 6. Convergence of Levallois and Folsom production techniques showing distal concavities, platform locations, direction of force, and distal and lateral views of products and by-products.

2010; Meltzer and Eren 2018)—must be "consistently imposed by the knapper and cannot be cheated; if it is incorrect, the physics does not work" (Lycett and von Cramon-Taubadel 2013:1514), and the successful production of a flute becomes impossible (Meltzer and Eren 2018). Second, the removal of increasingly fullfaced Folsom flute flakes would have also standardized point thickness across the surface area. As Turq (1992) showed, stone specimens with a more evenly distributed thickness of cross section have a greater potential for retouch and reuse. Eren and Lycett (2012) showed that preferential Levallois flakes possess these morphometric, and hence functional properties, and finished Folsom points may be similar (Ahler and Geib 2000), except in the case of Levallois, the removed flake is the item of use whereas in Folsom, the point "core" is the item of use. As the benefits of plan-view and thickness standardization became apparent, Folsom flutes would have become longer and the fluting process more standardized (Crabtree 1966; Frison and Bradley 1980; Judge 1973; Tunnell 1977).

\section{Conclusions}

Folsom bases and blades are less variable than Clovis bases and blades, which indicates increased point standardization during the Early Paleoindian period in the western United States. In addition, Clovis and Folsom point bases are no more variable than blades, which negates the claim that resharpening increases the shape variation of blades relative to bases. Finally, Clovis points, which are more variable in length, width, 
and shape than Folsom points, have more integrated base and blade segments than Folsom points. We propose that several classes of points intended for different functions may have been in use during the Clovis period and that, during the subsequent Folsom period, points may have served exclusively as weapon tips for hunting. We conclude that the uniformity of Folsom points was the result of constraints imposed by preparations for successful fluting.

Acknowledgments. Briggs Buchanan and Metin I. Eren are supported by the National Science Foundation (Award IDs: 1649406 and 1649395), and Metin I. Eren is supported by the Kent State University College of Arts and Science.

Data Availability Statement. The data used in this paper are available in the Supplemental Materials.

Supplemental Materials. For supplementary material accompanying this paper, visit https://doi.org/10.1017/aaq. 2018.53

Supplemental Table 1. Folsom and Clovis points included in the analysis by site.

Supplemental Table 2. Shapiro-Wilk Tests of Normality for Each Relative Warp (RW) Variable for Clovis $(n=125)$ and Folsom Points $(\mathrm{n}=156)$.

Supplemental Table 3. Mean and Coefficient of Variation of Clovis $(n=125)$ and Folsom $(n=156)$ Point Length and Width.

\section{References Cited}

Ahler, Stanley A., and Phil Geib

2000 Why Flute? Folsom Point Design and Adaptation. Journal of Archaeological Science 24:799-820.

Amick, Daniel S.

1994 Folsom Diet Breadth and Land Use in the American Southwest. PhD dissertation, Department of Anthropology, University of New Mexico, Albuquerque.

1996 Regional Patterns of Folsom Mobility and Land Use in the American Southwest. World Archaeology 27: 411-426.

Andrews, Brian N., Jason M. LaBelle, and John D. Seebach 2008 Spatial Variability in the Folsom Archaeological Record: A Multi-Scalar Approach. American Antiquity 73:464-490.

Bement, Leland C.

1999 Bison Hunting at Cooper Site: Where Lightning Bolts Drew Thundering Herds. University of Oklahoma Press, Norman.

2016 Assessing Flint Knapping Skill: An Analysis of the Beaver River Complex Folsom Point Assemblages, Northwest Oklahoma, USA. PaleoAmerica 2:159-168.

Boldurian, Anthony T.

1990 Lithic Technology at the Mitchell Locality of Blackwater Draw: A Stratified Folsom Site in Eastern New Mexico. Plains Anthropologist Memoir 24:35-130.

Boldurian, Anthony T., Philip T. Fitzgibbons, and Phillip H. Shelley
1985 Fluting Devices in the Folsom Tradition: Patterning in Debitage Formation and Projectile Point Basal Configuration. Plains Anthropologist 30:293-303.

Buchanan, Briggs, Brian Andrews, J. David Kilby, and Metin I. Eren

2018 Settling into the Country: Comparison of Clovis and Folsom Lithic Networks in Western North America Shows Increasing Redundancy of Toolstone Use. Ms. on file, Department of Anthropology, University of Tulsa, Oklahoma.

Buchanan, Briggs, and Mark Collard

2010 An Assessment of the Impact of Resharpening on Paleoindian Projectile Point Blade Shape Using Geometric Morphometric Techniques. In New Perspectives on Old Stones: Analytical Approaches to Paleolithic Technologies, edited by Stephen J. Lycett and Parth Chauhan, pp. 255-273. Springer, New York.

Buchanan, Briggs, Mark Collard, Marcus J. Hamilton, and Michael J. O'Brien

2011 Points and Prey: An Evaluation of the Hypothesis That Prey Size Predicts Early Paleoindian Projectile Point Form. Journal of Archaeological Science 38:852-864.

Buchanan, Briggs, Mark Collard, and Michael J. O'Brien

2014 Continent-Wide or Region-Specific? A Geometric Morphometrics-Based Assessment of Variation in Clovis Point Shape. Archaeological and Anthropological Sciences 6:145-162.

Buchanan, Briggs, Metin I. Eren, Matthew T. Boulanger, and Michael J. O'Brien

2015 Size, Shape, Scars, and Spatial Patterning: A Quantitative Assessment of Late Pleistocene (Clovis) Point Resharpening. Journal of Archaeological Science: Reports 3:11-21.

Buchanan, Briggs, Michael J. O’Brien, J. David Kilby, Bruce B. Huckell, and Mark Collard

2012 An Assessment of the Impact of Hafting on Paleoindian Projectile Point Variability. PLoS ONE 7(5):e36364.

Cannon, Michael D., and David J. Meltzer

2008 Explaining Variability in Early Paleoindian Foraging. Quaternary International 191:5-17.

Cheshier, Joseph, and Robert L. Kelly

2006 Projectile Point Shape and Durability: The Effect of Thickness:Length. American Antiquity 71:353-363.

Collard, Mark, Briggs Buchanan, Marcus J. Hamilton, and Michael J. O'Brien

2010 Spatiotemporal Dynamics of the Clovis-Folsom Transition. Journal of Archaeological Science 37: 2513-2519.

Crabtree, Donald E.

1966 A Stoneworker's Approach to Analyzing and Replicating the Lindenmeier Folsom. Tebiwa 9:3-39.

DeAngelis, Joseph A., and R. Lee Lyman

2016 Evaluation of the Early Paleo-Indian Zooarchaeological Record as Evidence of Diet Breadth. Archaeological and Anthropological Sciences 10:555-570. DOI:10.1007/s12520-016-0377-1, accessed August 1, 2017.

Dryden, Ian L., and Kanti V. Mardia

1998 Statistical Shape Analysis. Wiley, London.

Emery-Wetherell, Meaghan M., Brianna K. McHorse, and Edward B. Davis

2017 Spatially Explicit Analysis Sheds New Light on the Pleistocene Megafaunal Extinction in North America. Paleobiology 43:1-14.

Eren, Metin I., and Stephen J. Lycett

2012 Why Levallois? A Morphometric Comparison of Experimental "Preferential" Levallois Flakes versus 
Debitage Flakes. PLoS ONE 7(1):e29273. DOI: 10.1371/ journal.pone.0029273, accessed August 1, 2017.

Fligner, Michael A., and Timothy J. Killeen

1976 Distribution-Free Two-Sample Tests for Scale. Journal of the American Statistical Association 71: 210-213.

Frison, George C., and Bruce Bradley

1980 Folsom Tools and Technology of the Hanson Site, Wyoming. University of New Mexico Press, Albuquerque.

González-José, Rolando, and Judith Charlin

2012 Relative Importance of Modularity and Other Morphological Attributes on Different Types of Lithic Point Weapons: Assessing Functional Variations. PLoS ONE 7(10):e48009. DOI: 10.1371/journal.pone.0048009, accessed August 1, 2017.

Grayson, Donald K., and David J. Meltzer

2015 Revisiting Paleoindian Exploitation of Extinct North American Mammals. Journal of Archaeological Science 56:177-193.

Hammer, Øyvind, David A. T. Harper, and Paul D. Ryan

2001 PAST: Paleontological Statistics Software Package for Education and Data Analysis. Palaeontologia Electronica 4(1):1-9.

Hofman, Jack L.

1991 Folsom Land Use: Projectile Point Variability as a Key to Mobility. In Raw Material Economies among Prehistoric Hunter-Gatherers, edited by Anta Montet-White and Steven Holen, pp. 336-355. Publications in Anthropology No. 19. University of Kansas, Lawrence.

1992 Recognition and Interpretation of Folsom Technological Variability on the Southern Plains. In Ice Age Hunters of the Rockies, edited by Dennis J. Stanford and Jane Stevenson Day, pp. 193-224. Denver Museum of Natural History, Denver, Colorado.

1999 Unbounded Hunters: Folsom Bison Hunting on the Southern Plains circa 10,500 BP: The Lithic Evidence. In Le Bison: Gibier et Moyen de Subsistance des Hommes du Paléolithique aux Paléoindiens des Grandes Plains, edited by Jean-Philip Burgal, Francine David, James G. Enloe, and Jacques Jaubert, pp. 383-415. Éditions APCDA, Antibes, France.

2002 High Points in Folsom Archaeology. In Folsom Technology and Lifeways, edited by John E. Clark and Michael B. Collins, pp. 399-412. Lithic Technology Special Publication No. 4. Department of Anthropology, University of Tulsa, Tulsa, Oklahoma.

2003 Tethered to Stone or Freedom to Move: Folsom Biface Technology in Regional Perspective. In Multiple Approaches to the Study of Bifacial Technologies, edited by Marie Soressi and Harold L. Dibble, pp. 229-249. University of Pennsylvania Museum of Archaeology and Anthropology, Philadelphia.

Hunzicker, David A.

2008 Folsom Projectile Technology: An Experiment in Design, Effectiveness and Efficiency. Plains Anthropologist 53:291-311.

Hutchings, W. Karl

2015 Finding the Paleoindian Spearthrower: Quantitative Evidence for Mechanically-Assisted Propulsion of Lithic Armatures during the North American Paleoindian Period. Journal of Archaeological Science 55:34-41.

Jennings, Thomas A.

2012 Clovis, Folsom, and Midland Components at the Debra L. Friedkin Site, Texas: Context, Chronology, and Assemblages. Journal of Archaeological Science 39:3239-3247.
2016 The Impact of Stone Supply Stress on the Innovation of a Cultural Variant: The Relationship of Folsom and Midland. PaleoAmerica 2:116-123.

Jennings, Thomas A., Charlotte D. Pevny, and William A. Dickens

2010 A Biface and Blade Core Efficiency Experiment: Implications for Early Paleoindian Technological Organization. Journal of Archaeological Science 37:2155-2164.

Jodry, Margaret A. B.

1999 Folsom Technological and Socioeconomic Strategies: Views from Stewart's Cattle Guard and the Upper Rio Grande Basin, Colorado. PhD dissertation, Department of Anthropology, American University, Washington, DC. Judge, W. James

1973 PaleoIndian Occupation of the Central Rio Grande Valley in New Mexico. University of New Mexico Press, Albuquerque.

Kay, Marvin

1996 Microwear Analysis of Some Clovis and Experimental Chipped Stone Tools. In Stone Tools: Theoretical Insights into Human Prehistory, edited by George H. Odell, pp. 315-344. Springer, New York.

Kelly, Robert L., and Lawrence C. Todd

1988 Coming into the Country: Early Paleoindian Hunting and Mobility. American Antiquity 53:231-244.

Klingenberg, Christian Peter

2009 Morphometric Integration and Modularity in Configurations of Landmarks: Tools for Evaluating A Priori Hypotheses. Evolution and Development 11:405-421.

2011 MorphoJ: An Integrated Software Package for Geometric Morphometrics. Molecular Ecology Resources 11:353-357.

Kornfeld, Marcel, and Mary L. Larson

2008 Bonebeds and Other Myths: Paleoindian to Archaic Transition on North American Great Plains and Rocky Mountains. Quaternary International 191:18-33.

Lycett, Stephen J., and Noreen von Cramon-Taubadel

2013 A 3D Morphometric Analysis of Surface Geometry in Levallois Cores: Patterns of Stability and Variability across Regions and Their Implications. Journal of Archaeological Science 40:1508-1517.

Lycett, Stephen J., Noreen von Cramon-Taubadel, and John A. J. Gowlett

2010 A Comparative 3D Geometric Morphometric Analysis of Victoria West Cores: Implications for the Origins of Levallois Technology. Journal of Archaeological Science 37:1110-1117.

Meltzer, David J.

2009 First Peoples in a New World: Colonizing Ice Age America. University of California Press, Berkeley.

2015 Pleistocene Overkill and North American Mammalian Extinctions. Annual Review of Anthropology 44:33-53.

Meltzer, David J., and Metin I. Eren

2018 The Mountaineer Folsom Projectile Point Assemblage. Manuscript on file, Department of Anthropology, Southern Methodist University. Dallas, Texas.

Meltzer, David J., and Vance T. Holliday

2010 Would North American Paleoindians Have Noticed Younger Dryas Age Climate Changes? Journal of World Prehistory 23:1-41.

Miller, G. Logan

2013 Illuminating Activities at Paleo Crossing (33ME274) through Microwear Analysis. Lithic Technology 38: 97-108.

O'Higgins, Paul

2000 Quantitative Approaches to the Study of 
Craniofacial Growth and Evolution: Advances in Morphometric Techniques. In Development, Growth and Evolution: Implications for the Study of the Hominid Skeleton, edited by Paul O'Higgins and Martin J. Cohn, pp. 163-185. Academic Press, London.

Patten, Robert J.

2002 Solving the Folsom Fluting Problem. In Folsom Technology and Lifeways, edited by John E. Clark and Michael B. Collins, pp. 299-308. Lithic Technology Special Publication No. 4. Department of Anthropology, University of Tulsa, Tulsa, Oklahoma.

2005 Peoples of the Flute: A Study in Anthropolithic Forensics. Stone Dagger, Denver, Colorado.

Razali, Nornadiah M., and Yap B. Wah

2011 Power Comparisons of Shapiro-Wilk, KolmogorovSmirnov, Lilliefors and Anderson-Darling Tests. Journal of Statistical Modeling and Analytics 2:21-33.

Rohlf, F. James

1993 Relative Warp Analysis and an Example of Its Application to Mosquito Wings. In Contributions to Morphometrics, edited by Leslie F. Marcus, Elisa Bello, and Antonio García-Valdecasas, pp. 131-159. Museo Nacional de Ciencias Naturales, Madrid.

2015a tpsSuper version 2.02 Shareware Program. Electronic document, http://life.bio.sunysb.edu/morph, accessed August 1, 2017.

2015b tpsSmall version 1.33 Shareware Program. Electronic document, http://life.bio.sunysb.edu/morph, accessed August 1, 2017.

2016 tpsRelw version 1.62 Shareware Program. Electronic document, http://life.bio.sunysb.edu/morph, accessed August 1, 2017.

Rohlf, F. James, Anna Loy, and Marco Corti

1996 Morphometric Analysis of Old World Talpidae (Mammalia, Insectivora) Using Partial-Warp Scores. Systematic Biology 45:344-362.

Root, Matthew J., Jerry D. William, Marvin Kay, and Lisa K. Shifrin

1999 Folsom Ultrathin Biface and Radial Break Tools in the Knife River Flint Quarry Area. In Folsom Lithic Technology: Explorations in Structure and Variation, edited by Daniel S. Amick, pp. 144-168. International Monographs in Prehistory, Ann Arbor, Michigan.

Sellet, Frédéric

2018 My Flute Is Bigger Than Yours: Nature and Causes of Technological Changes on the American Great Plains at the End of the Pleistocene. In Lithic Technological Organization and Paleoenvironmental Change, edited by Erick Robinson and Frédéric Sellet, pp. 263-279. Springer, New York.

Slice, Dennis E.

2007 Geometric Morphometrics. Annual Review of Anthropology 36:261-281.

Slice, Dennis E. (editor)

2005 Modern Morphometrics in Physical Anthropology. Kluwer, New York.

Smallwood, Ashley M.

2006 Use-Wear Analysis of the Clovis Biface Collection from the Gault Site in Central Texas. Master's thesis, Department of Anthropology, Texas A\&M University, College Station.

Straus, Lawrence, and Ted Goebel

2011 Humans and Younger Dryas: Dead End, Short
Detour, or Open Road to the Holocene? Quaternary International 242:259-261.

Surovell, Todd A.

2009 Toward a Behavioral Ecology of Lithic Technology: Cases from Paleoindian Archaeology. University of Arizona Press, Tucson.

Surovell, Todd A., Joshua R. Boyd, C. Vance Haynes Jr., and Gregory W. L. Hodgins

2016 On the Dating of the Folsom Complex and Its Correlation with the Younger Dryas, the End of Clovis, and Megafaunal Extinction. PaleoAmerica 2:81-89.

Surovell, Todd A., Spencer R. Pelton, Richard AndersonSprecher, and Adam D. Myers

2016 Test of Martin's Overkill Hypothesis Using Radiocarbon Dates on Extinct Megafauna. Proceedings of the National Academy of Sciences 113:886-891.

Thomas, Kaitlyn A., Brett A. Story, Metin I. Eren, Briggs Buchanan, Brian N. Andrews, Michael J. O'Brien, and David J. Meltzer

2017 Explaining the Origin of Fluting in North American Pleistocene Weaponry. Journal of Archaeological Science 81:23-30.

Thulman, David K.

2012 Discriminating Paleoindian Point Types from Florida Using Landmark Geometric Morphometrics. Journal of Archaeological Science 39:1599-1607.

Tunnell, Curtis

1977 Fluted Projectile Point Production as Revealed by Lithic Specimens from the Adair-Steadman Site in Northwest Texas. In Paleoindian Lifeways, edited by Eileen Johnson, pp. 141-168. West Texas Museum Association, Lubbock.

Tunnell, Curtis D., and LeRoy Johnson

2000 Comparing Dimensions for Folsom Points and Their By-Products from the Adair-Steadman and Lindenmeier Sites and Other Localities. Archaeological Reports Series No. 1. Texas Historical Commission, Austin.

Turq, Alain

1992 Raw Material and Technological Studies of the Quina Mousterian in Perigord. In The Middle Paleolithic: Adaptation, Behavior, and Variability, edited by Harold L. Dibble and Paul Mellars, pp. 75-85. University of Pennsylvania Museum of Archaeology and Anthropology, Philadelphia.

Waters, Michael R., and Thomas W. Stafford

2007 Redefining the Age of Clovis: Implications for the Peopling of the Americas. Science 315:1122-1126.

2014 The First Americans: A Review of the Evidence for the Late-Pleistocene Peopling of the Americas. In Paleoamerican Odyssey, edited by Kelly Graf, Caroline V. Ketron, and Michael R. Waters, pp. 541-560. Texas A\&M University Press, College Station.

Wilmsen, Edwin N., and Frank H. H. Roberts

1978 Lindenmeier, 1934-1974: Concluding Report on Investigations. Smithsonian Institution Press, Washington, DC.

Wormington, H. Marie

1957 Ancient Man in North America. Denver Museum of Natural History, Denver, Colorado.

Submitted January 26, 2018; Revised April 16, 2018;

Accepted May 7, 2018 